\title{
Ecofriendly Synthesis of Antifungal Azoles
}

\author{
Kidwai, M. ${ }^{*}$ and Mohan, $R$.

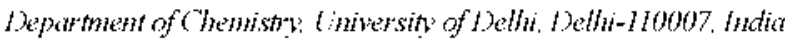 \\ (20)(10. 10.8 점 ${ }^{2}=$
}

\section{Ecofriendly Synthesis of Antifungal Azoles}

\author{
Kidwai, M. * and Mohan, R.

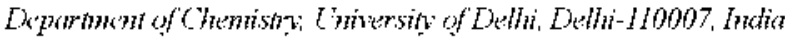

(Recived October 8. 2003)

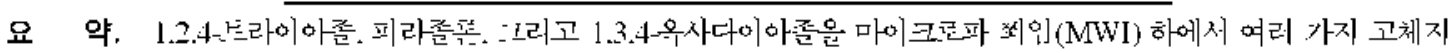
지체를 이용하혀 치환기가 있는- 하이드라사이드룬부터 합성히었다. 고 얻어진 실힘 견과들은 고체지지체의 다양성문 너-

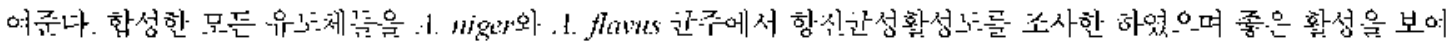
주ㅇㅓㅓㅆㄷㅏ.
\end{abstract}

주제어: 고체지지체. 마이크론파 쬐익. 항진규성 활성도. 드라이하존. 피라존폰. 옥사다이아졸

\begin{abstract}
Triazoles, pyrazolones and 1.3,4-oxadianoles have been synthesized from substituted hydrazide using farious solid supports under microwave irradiation (MWI). The results oblained highlight the versalility of the solid supporls. $A 11$ symthesized compounds were screened for their antilungal activity against i. nger and i. flavis and were found to possess good activity
\end{abstract}

Keywords: Solid Support. Meronave Iradiation (MWI). Antifungal Activity. Triazoles. Pyrazolones. Oxadiazoles

\section{INTRODUCTION}

The increasing emvirommental conscioushess throughout the world has put a pressing need to develop an alternate sinthetic approach for biologically and synthetically important componds. Inorganic solid supports (aluminas, silicas, foolites, clays) coupled with microwaves bave made a landmark in this direction as reactions can be perlomed in dry media or under solventless conditions. ${ }^{1.2}$ Aluminas can he seloctod as acidic or hasic calalys depending on the type of organic reaction. Montmorillonite clays such as $\mathrm{K} 10$ ofter acidities very close to nitric acid or sulfuric acid. ${ }^{3}$ Moreover, these mineral oxides act as an efticient energy transfer medium.

1,2,4-Triazoles, pyrazolones and 1,3,4-oxadiazoles are associated with broad spectrum of biologi- cal activities including antifungal, antibacterial, anti-inflanmatory; antihistaninic, analgesic and antitumor properties. ${ }^{1-1}$ several methods for the synthesis of these biologically active compounds are reported in literature. ${ }^{10.1]}$ I Iy drazide derivatives have been extensively used as a good precursor for the synthesis of these derivalives. ${ }^{12.13}$ Keeping in view the biological impertance of the above mentioned heterocyelic compounds and in continuation to our endeaseur towards environmentally benign synthesis. $^{11}$ we report herein the synthesis of $3-[$ (2-henzovlaminopheny 17-1,2,4-triazolin-5-thione 2a,h. 3methy $1-1-[(2-b e n z o y l a m i n o)) b e n z o r 1]-5$-pyrazolone 3a,b and 2-[(2-benzoylamino) pheny 1$]-5$-ary $]-1.3,4-$ oxadiazoles 4a,b from 2-(benzoslamino) benzoic hydrazide la and 2-benzoylaminobenzoic phenylhydrazide lb using different solid supports under 
MWI. These derivatives were werned for their antifungal activity against $A$ niger and $A$ flows.

\section{EXPERIMENTAL SECTION}

Melting points were determined on a lhomas lloover melting point apparatus and are uncorrected. IR spectra were recorded on a Perkin-Finer FTIR-17I0 spetrophetometwe. 'H NMR were noorded on FT NMR Hitachi R-600 (60) MH $\%$ ) instrument using tetranethy silane as reterence. Micrmave inadiation was carried in Kenstar Micronave Oven, Model No. OM9925Г. (2450 MH $/, 800 \mathrm{~W}$ ). Elemental analysis were pertomed by means of lleraeus CIIN-Rapid Analyzer. The progress of reaction was monitored on silica gel coated $\mathrm{Nl}$ plates (Merck). lemperature of the reaction mixture was measured through $\Lambda Z$. Non-Contact IR themometer. Model No. 8868.

General Procedure for the synthesis of 3-[(2-benzoylamino)phenyll-1,2,4-triazolin-5-thione (2a,b)

Compound la,b was prepared according to the litcrialurt mothed. ${ }^{\text {15.16 }}$

Tabke 1 . Anlitingal Activity ol Compounds (2a, b; 3a, b; 4a, b)

\begin{tabular}{|c|c|c|}
\hline Compd No. & $\begin{array}{c}\text { Inhibition of . I. niger } \\
(50 \mu \mathrm{g} \mathrm{mL})\end{array}$ & 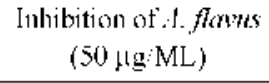 \\
\hline $2 a$ & -++ & --+ \\
\hline $2 \mathbf{b}$ & -++ & -+-+ \\
\hline 3a & -+-+ & -++-+ \\
\hline $3 \mathbf{b}$ & -+-+ & -++-+ \\
\hline ta & .11 & 1. \\
\hline$+\mathbf{b}$ & $\cdot 1 \cdot 1$ & 1. \\
\hline Salicyclic acid & $\cdot 1 \cdot 1$ & $\cdot 1 \cdot 1$ \\
\hline
\end{tabular}

Basic alumina/neutral alumina ${ }^{15}(20 \mathrm{~g})$ was added to a solution of $\mathbf{1 a , b}(0.01 \mathrm{~mol})$ and anmonium thiocyanate $(0.01 \mathrm{~mol})$ in ethanol $(20 \mathrm{~mL})$ at room temperature. The reaction mixture was thoroughly mixed and air dried (in $100 \mathrm{~mL}$ beaker). It was then placed in an alumina bath inside the microwave oven and irradiated intermittently at 30 s intervals lor the specified line (Table 2). On completion of reaction, as monitored by TIC examination (at an interval of $30 \mathrm{~s}$ ), the product was extracted into chlorolom $(3 \times 10 \mathrm{~mL})$. Removal of solvent under redueed pressure gave the desired product (Tahle 2) which was rocystallized from cthanol

General Procedure for the synthesis of 1-[(2-henzoylamino)benzoyl-3-methyl-5-pyrawolone (3a,b)

lo the ethanolic (20) ml) solution of $\mathbf{1 a}, \mathbf{b}(0.01$ $\mathrm{mol}$ ) and ethyl acetoacetate $(0.01 \mathrm{~mol})$ in $100 \mathrm{ml}$ beaker, neutral alumina $(20$ g) was added. The reaction misture was stirred well and dried in air. It was placed in an alumina bath and subjected to MWI intemittently at an interal of 30 s lor specified time (Toble 2). On completion of reaction, as monitored by TI,C examination (at an interval of $30 \mathrm{~s}$ ). the product was extracted into ethanol $(3 \times 10 \mathrm{mI}$.). Removal ol solvent under reduced pressure gare the desired product (fable 2) which was recrystallized from ethanol.

General Procedure for the synthesis of 5-[2-(benzoylamino)phenyll-2-aryl-1,3,4-Oxadiazole $(+a, b)$

To the ethanolic solution of $1 \mathrm{a}(0.01 \mathrm{~mol})$ and carboxylic acid $5 \mathbf{a}, \mathbf{b}(0.01 \mathrm{~mol})$ in $100 \mathrm{ml}$ beaker. acidic alumina montmorillonice K/O clay $(20 \mathrm{~g})$ was added. The reaction mixture was stired well and dricd in air. It was then placed in an alumina hath and subjected to MWI intermittently at an

Table 2. Comparison of Reaction Tinc \& Yicld for Compounds $(2 \mathbf{a}, \mathbf{b} ; 3 \mathbf{3}, \mathbf{b} ; \mathbf{4 a}, \mathbf{b})$

\begin{tabular}{|c|c|c|c|c|c|}
\hline \multirow{2}{*}{ Compd. No. } & \multirow{2}{*}{ m.p. $\left({ }^{\circ} \mathrm{C}\right)$} & \multicolumn{2}{|c|}{ Conrentional Heating Solution Phase } & \multicolumn{2}{|c|}{ Microwate Heating Solid Support } \\
\hline & & Time (hr) & o Yield & Time (min) & no Yield \\
\hline 2a & 175 & 3.0 & 77 & $2.5^{a}(2.0)^{\mathrm{h}}$ & $92^{a}(9) y^{k+1}$ \\
\hline $2 b$ & 188 & 3.5 & 76 & $3.5^{a}(2.5)^{\mathrm{h}}$ & $90^{\mathrm{a}}(9) y^{\mathrm{th}}$ \\
\hline $3 a$ & 192 & $4 . \overline{5}$ & 74 & 5.0 & 87 \\
\hline $\mathbf{3 b}$ & 180 & 6.0 & 75 & 6.0 & 88 \\
\hline 4a & 168 & 4.0 & 77 & $7.0^{\circ}(7.5)^{\mathrm{l}}$ & $89^{c}(87)^{\mathrm{l}}$ \\
\hline $\mathbf{t b}$ & 179 & 5.5 & 72 & $6.5^{\mathrm{c}}(7.5)^{\mathrm{d}}$ & $90^{c}(86)^{\mathrm{l}}$ \\
\hline
\end{tabular}

Nental alumina: 'Basic alumina: 'Acidic alumina: "Montmonillonite K 10 day: 
inlerval of $30 \mathrm{~s}$ for specilied time (Table 2). On completion of reaction, as monitored by ILC examination, the product was extracted into ethanol $(3 \times 15 \mathrm{~mL})$. Removal of solvent under reduced pressure gave the desired product (fable 2) which was recrystallized from ethanol.

\section{RESULTS AND DISCUSSION}

The hy drasides la,b were prepared by treating 2-

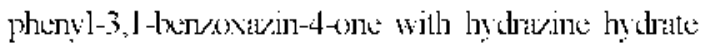
and phenylhydrayme respectively. ${ }^{1510}$ Condensation of la,b with ammonium thiocyanate was carried over basic/neutral alumina under MWI to give 3-substituted-1,2.4-triazolin-5-thione 2a,b. 'This was evidenced by appearance of IR absorption band at $1240 \mathrm{~cm}^{-1}\left(C^{\prime}=\mathrm{S}\right)$ and $1580 \mathrm{~cm}^{-1}(\mathrm{C}=\mathrm{N})$ and appearance of signal for NI $I$ at $\delta 8.3$ in 'II NMR spectrum. lime taken for the completion of reaction using basic alumina was less than that with neutral alumina though the yiclds were comparable (Tohle 2). This is because in hasic media the increase in nucleophilicity of nitrogen leads to attack at carbonyl carbon through nitrogen.

Condensation of la,b with ethyl aceloacetale using neutral alumina afforded the 3-methyl-1-substituted-5-pytazolone 3a,b. The fomation of the compounds was evidenced by the disappearance of IR band at $1720 \mathrm{~cm}^{-1}$ due to $C=O$ of ester and appe parance of band at $1660 \mathrm{~cm}^{-1}$ due to $C=0$ of prtazolone ting. In ${ }^{1} 11$ NMR signal at $\delta 5.5$ due to
H-4 proton and at $\delta 2.3$ due to methyl protons were present.

In continuation of our earlier effort for novel route towats swntheris of 2,5-disubstituted-1,3,4-osadiazole ${ }^{1^{-}}$, 1a,b when condensed with aromatic carbonylic acids $\mathbf{5} \mathbf{a}, \mathbf{b}$ under MWI using acidic alumina/montmorillonite $\mathrm{K} 10$ clay ${ }^{18}$ gave new $1,3,4$-oxadiazoles in good yield in casc of la only, while no product was obtained $w$ ith $\mathbf{l b}$ even alter irradialing lor long time. Moreover, the fomation of inkemediate diacyllydrazide was not observed in this case. This is due to the decrease in the nueleophilicity of nitrogen in acidie media and also the presence of electron withdrawing phenyl group. The structure of the compound was established by the appearance of IR band at $1590 \mathrm{~cm}^{-1}(\mathrm{C}=\mathrm{N})$ and disappearance of band at $1725 \mathrm{~cm}^{-1}(\mathrm{C}=0)$ of carbosy lic acid. The band at $1337 \mathrm{~cm}^{-1}$ (C-O-C) characteristic of cyclic ether further confirmed the formation of products.

Tilemental analysis of all compounds was done (Toble 3). The compounds $\mathbf{2 a , b}, \mathbf{3 a}, \mathbf{b}$ and $\mathbf{4 a}, \mathbf{b}$ were also synthesized under conventional healing. The drastic reduction in reaction time and improyement in yicld on going from conventional synthesis to microwave assisted solid support synthesis (Toble 2) can be attributed to the uniform heating effect of microwaves. Reaction pathways are depicted in Scheme 1.

All compounds were screened for their antifungal activity against 1 . niger and 1 . flows by the paper dise diffision method. ${ }^{18}$ The zone of inhibi-

Table 3. Spectral and Analytical Data of the Compounds (2a. 2b: 3a. 3b: 4a 4b)

\begin{tabular}{|c|c|c|c|c|c|}
\hline \multirow{2}{*}{\multicolumn{2}{|c|}{ Compd. No. IR (v. KBr pellets) $\mathrm{cm}^{-1}$}} & \multirow{2}{*}{ 'H NMR (ס. ppm $\left.\mathrm{CDCl}_{3}\right)$} & \multicolumn{3}{|c|}{${ }_{0}^{\circ}$ CHN. Found (Caled.) } \\
\hline & & & C & $\mathrm{H}$ & $\mathrm{N}$ \\
\hline \multirow[t]{2}{*}{$2 a$} & $3420.3210(\mathrm{~N}-\mathrm{H}) .1670(\mathrm{C}-\mathrm{O})$ & $7.2-7.7(\mathrm{~m} .9 \mathrm{H} . \mathrm{Ar}-\mathrm{H}):$ & 60.78 & 4.07 & 18.90 \\
\hline & $1240(\mathrm{C}-\mathrm{S}) .1580(\mathrm{C}-\mathrm{N})$ & $8.3($ br. 2 H. $2 \times N H)$ & $(60.81)$ & $(4.05)$ & (18.91) \\
\hline \multirow[t]{2}{*}{$2 b$} & $3218(\mathrm{~N}-\mathrm{H}) .1678(\mathrm{C}-\mathrm{O})$ & $7.2-7.8(\mathrm{~m} .14 \mathrm{H}$. Ar-H) & 67.75 & 4.33 & 15.07 \\
\hline & $1580(\mathrm{C}-\mathrm{N}) .1245(\mathrm{C}-\mathrm{S})$ & 8.4 (br. 1 H. NH) & $(67.74)$ & $(4.30)$ & $(15.05)$ \\
\hline \multirow[t]{2}{*}{$3 a$} & $3420.3280(\mathrm{~N}-\mathrm{H})$ & $2.3\left(\mathrm{~s} .3 \mathrm{H} . \mathrm{CH}_{4}\right) .5 .5(\mathrm{~s} . \mathrm{H} . \mathrm{CH})$ & 67.30 & 4.68 & 13.10 \\
\hline & $1700.1685 .1680(\mathrm{C}-0)$ & $7.3-8.0($ m. 9 H. ArH). 8.4 (br. 1 H. NH) & $(67.28)$ & $(4.67)$ & $(13.08)$ \\
\hline \multirow[t]{2}{*}{$3 \mathbf{b}$} & $3440(\mathrm{NH}), 1695.1685$ & $2.4\left(\mathrm{~s} .3 \mathrm{H} . \mathrm{CH}_{4}\right) .5 .4(\mathrm{~s} . \mathrm{H} . \mathrm{CH})$ & 72.56 & 4.75 & 10.58 \\
\hline & $1680(\mathrm{C}-0)$ & $7.3-8.0(\mathrm{~m} .14 \mathrm{H} . \mathrm{Ar}-\mathrm{H})$ & (72.54) & $(4.78)$ & $(10.57)$ \\
\hline \multirow[t]{2}{*}{ ta } & $1590(C-N)$ & $7.2-8.3(\mathrm{~m}, 14 \mathrm{II}, \mathrm{Ar}-\mathrm{H})$ & 73.91 & 4.35 & 12.29 \\
\hline & $1339(\mathrm{COC})$ & $10.8(\mathrm{br}, 1 \mathrm{II}, \mathrm{NII})$ & $(7.3 .90)$ & $(4 . .39)$ & $(12.31)$ \\
\hline \multirow[t]{2}{*}{ th } & $156+(\mathrm{C}-\mathrm{N}) \cdot 1.337(\mathrm{COC})$ & $5.5(\mathrm{~s}, 1 \mathrm{II}, \mathrm{OIJ}, 7.0-7.8(\mathrm{~m}, 1.3 \mathrm{II}, \wedge \mathrm{r}-\mathrm{H})$ & 70.60 & 4.22 & 11.75 \\
\hline & $3.308(\mathrm{OH})$ & $10.7(\mathrm{br}, \mathrm{III}, \mathrm{NII})$ & $(70.58)$ & $(4.20)$ & $(11.76)$ \\
\hline
\end{tabular}


<smiles>[R]NNC(=O)c1ccccc1NC(=O)O</smiles>

1a,b $\mathrm{R}^{\prime}=\mathrm{H}, \mathrm{C}_{6} \mathrm{H}_{5}$

\section{$\mathrm{NH}_{4} \mathrm{SCN}$}

Basic/Neutral Alumina

$\mu v$<smiles>[R]n1nc(-c2ccccc2N=C(C)OCCCCCCC)[nH]c1=S</smiles>

2a,b<smiles>[R]n1c(C)cc(=O)n1C(=O)c1ccccc1Nc1ccccc1</smiles>

3a,b

$\mu v$<smiles>[R]c1nnc(-c2ccccc2NC(=O)OCc2ccccc2)o1</smiles>

No reaction when $\mathrm{R}^{\prime}=\mathrm{C}_{6} \mathrm{H}_{5}$$$
\text { Montmorillonite K } 10 \text { Clay }
$$$$
\mu \nu
$$

$$
\begin{aligned}
\mathrm{R}: \mathrm{a} & =\mathrm{C}_{6} \mathrm{H}_{5} \\
\mathrm{~b} & =p-\mathrm{HOC}_{6} \mathrm{H}_{4}
\end{aligned}
$$$$
\text { Acidic Alumina / }
$$

Scheme 1

tion was measured in millimeters. The antifungal activities of the test compounds were compared to standard salicylic acid (17-21 mm). DMF was used as solvent. All compounds have shown good activity against both lungi. llowever, pyrazolone derivatives 3a,b have shown cxcellent antifungal activity (20-22 mm) against both $A$. niger and $A$. flonus. Compound $\mathbf{4 a , b}$ showed better activity $(15-17 \mathrm{~mm})$ against $A$. niger as compared to aclivily (11-13 mm) against A. flavus (Table 1).

\section{REFERENCES}

1. Varma R.S. Geen Chem. 1999,, 43.

2. Kidwai. M. Pute Appl. Chem. 2001, 73(1), 147.

3. (a) Smith. K. Solid Supports and Catalysis in Organic Synthesis r.d. Fillis Honwood. PTR Prentice Hall: Chichester, 1992. (b) Clark. J.H. Catalysis of Organic Reactions by Supported Inorganic Rcagents VCH:
Weinhein. 1994.

4. Gan. Y.: Lu. L.: Liu. J.: Tïenn. M. Zhongguo Kanur Zachi. 2001. $/(2) .85$ : (7wm. Abstr. 2002. 136. 216696.

5. Iuran-Zitouni. (j.: Sivaci. M.: Kilic. F.S.: Erol. K. Eurr: d. Wed. (hem. 2001. 36(7-8). 685.

6. Elguero. J. Comprehensive I leterocyclic Chemistry: The Structure. reaction. synthesis and uses of heterocyclic compounds. ed. K.I. I'olts. P'ergemon Press. 1984. 5. 167.

7. Girges. M.M.: Abou El-Zahab. M.M.: tlanna. M.M. Arch Phametcat Res. 1988. $/ 1(3) .169$.

8. Thang. 7.: Fang. X.: Chen, $\mathrm{I}_{\text {:. }}$ : Mong, Y.: 7heng. I.: Chen, M.: I.iu, Y: Xucbao. I.O. T.imon Kermebon. 1992, 28, 103: (hemt. Absts. 1993, 1/9, 95436.

9. Sharme S. Srivastava V.K.: Kumar, A. Ftu: $J$. Hed. (Chem., 2002, 37(8), 689.

10. (a) Brown, H.C.: Wetzel, C.R. J. Org. Chem. $1965,30$. 3729. (b) Jung. J.C.: Wathins, Г.. B.: Avery. M.A. Tetrahedron, 2002, $58(18), 3639$.

11. (a) Abluwalia. V.K.: Dudeja. S. Sinth. Conmmm., 2001. 
3I(20) . 3175. (b) Rigo. B.: Caulies.l'. Sinth. Commm. . 1998. $I s(H)$. 1247. (c) Goddart. C. J. Hetkrocictic C/k:m. 1991. 28. 17.

12. (a) Sharma. R.S.: Bahel. S.C. J. Ind Ch'm. Soc.. 1982. 59. 877. (b) Shiba. S.A.: El-Khamr. A.A.: Shaban. M.Г.: Atia, K.S. Indiam J. ('hem. 1997, 36B. 361.

13. (a) Jung J.C.: Watkins, Г. B: Avery. M.A. Symh ('ommm. 2002, 32(2f). 3767. (b) Socher, R.; Csongar. C: Müller. I.: Tomaschewski, G. Z. ("hem. 1981, 21, 182. (c) Scherowsky. G.: Kundu, B. Temahedwn Letf, 1972. 3169 .

14. (a) Kidwai. M: Saxena. S.: Mohat, R: Venkataramanan. R. J. (Them. Soc.. Perkin Trans. 1. 2002. 16. 1845. (b) Kidwai, M.: Rastogi, S.: Venkataramanat, R. Fill. ( $h$ hm. $S_{o c} . J p h ., 2003.76 .203$.
15. Sammour. A.: Selim. M.I.E.: Abdo. M. J. Chum. L.A.R. 1971. 14 .

16. Abdalla. M.M.: E'-Kady. M.: El-Furargy. A.5. Esqpt, $J$, Chem. 1977. 20. 245.

17. Kidwai. M.: Moluan. K. Ong. Irok. Inzp. Int. 2003. 35. 426 .

18. (a) Numinium oxide, acidic, Brocktmant I (- 150 mesh, $58 \wedge$. САMAG $506-\mathrm{C}-1$, surtace area $\left.155 \mathrm{~m}^{2}: \mathrm{g}\right)$. (b) Montmorillonite K10 clay, Aldrich 11.6168 . surtace area 220-270 $\mathrm{m}^{2} \mathrm{~g}$. Bulk density $300-370 \mathrm{~g}$ I. (c) Aluminium oxide neutral. Brexkmann I (Aldrich Chem. Co. Cat. No. 19, 997-4. - 150 mesh, $58 \AA$. surtace area 155 $\mathrm{m}^{2} \mathrm{~g}$ ). (d) Aluminium oxide basic. Brockmantm I ( Aldrich Chem. Cat. No. 19,944-3. $\cdots 150$ mesh, 58 А. surface arca $155 \mathrm{~m}^{2} \mathrm{~g}$ ) 